\title{
Projects and Their Management: A Literature Review
}

\author{
Guru Prakash Prabhakar \\ Bristol Business School \\ University of the West of England \\ Coldharbour Lane, Frenchay Campus \\ Bristol- BS16 1QY, UK
}

Tel: 44-117-328-3461Ｅ-mail: guru.prabhakar@uwe.ac.uk

\begin{abstract}
Over the years and more importantly in the recent past projects have been used as a delivery mechanism to do business and accomplish objectives. No wonder it has become one of the fastest growing professions in the world. Although the understanding of what constitutes a project and what doesn't continues to be a topic of debate. This paper attempts to provide literature search on what is a project, its classification, characteristics, its life cycle, phases, tools etc.
\end{abstract}

Keywords: Projects, Project Management

Every one of us is a manager of projects! From a house wife to a production employee to financial analyst, from banker to physician, from engineer to administrator, from teacher to student, we all work on various tasks with deadlines. Regardless of our occupation, discipline, or location in an organization, we all work on tasks that are unique and involve people who do not usually work together. The project may have a simple objective that does not require many people or a great deal of money, or it may be quite complex, calling for diverse skills and many resources. But the bottom line is that every one of us manages projects!

\section{What is a Project?}

While there are several definitions of projects in the literature, one of the best has been offered by Tuman (1983), who states:

"A project is an organization of people dedicated to a specific purpose or objective. Projects generally involve large, expensive, unique, or high risk undertakings which have to be completed by a certain date, for a certain amount of money, with some expected level of performance. At a minimum, all projects need to have well defined objectives and sufficient resources to carry out all the required tasks."

In lines of the definition provided by Pinto \& Slevin (1988), and accepted for the purpose of this research, a project can be defined as possessing the following characteristics:

(1) A defined beginning and end (specified time to completion)

(2) A specific, preordained goal or set of goals (performance expectations)

(3) A series of complex or interrelated activities

(4) A limited budget

Diallo \& Thuillier (2003) reviewed the project management literature outlined a set of evaluation dimensions which appear regularly although not with the same occurrence:

(1) Respect to the three traditional constraints

(2) Satisfaction of the client

(3) Satisfaction of the objectives as outlined in the logical framework

(4) Project impacts

(5) Institutional or organizational capacity built in the organization by the project

(6) Financial returns (in the case of productive projects) or the economic or social benefits (in the case of public sector projects), and

(7) Project innovative features (outputs, management or design) 
In the words of Turner (1999), "a project is an endeavour in which human, financial and material resources are organized in a novel way to undertake a unique scope of work, of given specification, within constraints of cost and time, so as to achieve beneficial change defined by quantitative and qualitative objectives."

As defined in A Guide to the Project Management Body of Knowledge (PMI, PMBOK ${ }^{\circledR}$ Guide, 2000), a project is a temporary endeavor undertaken to create a unique product or service. Temporary means that every project has a definite beginning and a definite end. Unique means that the product or service is different in some distinguishing way from all other projects or services.

Declerck et al., $(1983,1997)$, illustrate the political perspective of projects in this way: "a project is a whole of actions limited in time and space, inserted in, and in interaction with a politico-socio-economic environment, aimed at and tended towards a goal progressively redefined by the dialectic between the thought (the project plan) and the reality."

Gittinger (1972) defines projects as a whole complex of activities involved in using resources to gain benefits. Gittinger (1982) explains that generally projects form a clear and distinct portion of a larger, less precisely identified program. The whole program might possibly be analyzed as a single project, but by and large it is better to keep projects rather small, close to the minimum size that is economically, technically, and administratively feasible. If a project approaches program size, there is a danger that high returns from one part of it will mask low returns from another. Project is an activity for which money will be spent in expectation of returns and which logically seems to lend itself to planning, financing, and implementing as a unit. It is a specific activity, with a starting point and a specific ending point, intended to accomplish specific objectives. Usually it is a unique activity noticeably different from preceding, similar investments, and it is likely to be different from succeeding ones, not a routine segment of ongoing operations. It will have a well-defined sequence of investment and production activities, and a specific group of benefits, that we can identify, quantify, and usually determine a money value for. Often a project will have a partially or wholly independent administrative structure and set of accounts and will be funded through a specially defined financial package.

As maintained by Nilsson \& Söderholm (2005), planning and plans are intrinsic features of projects. Plans are meant to constitute and guide project team members as they work on realizing what ever project goals that have been set out for them. A plan can, however, only have a certain degree of sophistication. When project management practices on a day-to-day basis are examined, plans seem to dissolve and become less prescriptive.

\section{Characteristics of a Project}

Typically, most projects share most if not all of the five characteristics listed below.

(1) A start and a finish

(2) A time frame for completion

(3) An involvement of several people on an ad-hoc basis

(4) A limited set of resources

(5) A sequencing of activities and phases

\section{Classification of Projects within Categories and Sub-Categories}

(1) Project size

(2) Project complexity

(3) External or internal customer

(4) Degree of customer involvement in the project

(5) Levels of risk in projects

(6) Major and minor projects within a category

According to Gareis and Huemann (2000) the Project-oriented Company (POC) is an organisation which defines "Management by Projects" as an organisational strategy, applies temporary organisations for the performance of complex processes, manages a project portfolio of different project types, has specific permanent organisations to provide integrative functions, applies a "New Management Paradigm", has an explicit project management culture, and perceives itself as being project-oriented. Thus POCs do have specific processes, such as assignments of projects and programmes, project management, programme management, quality management of projects and programmes, project portfolio co-ordination, networking between projects, personnel management in the POC and organisational design of the POC. 


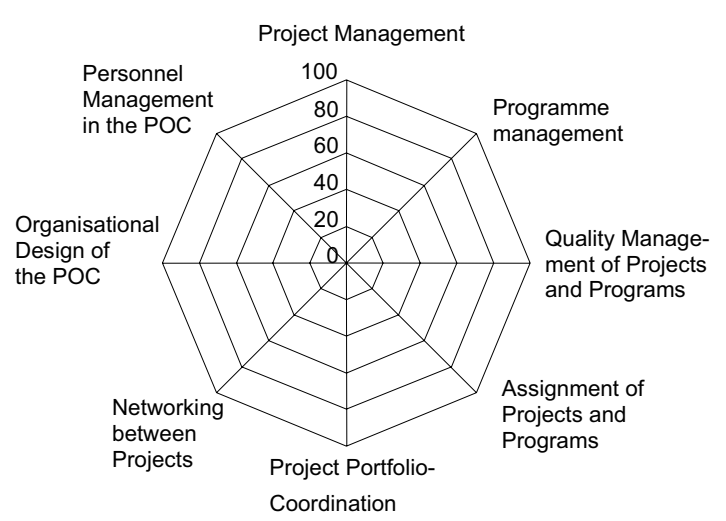

Exhibit 1: Specific Processes of the Project-oriented Company, Gareis and Huemann (2000).

\section{Project Management as defined by some leading writers}

"Project Management as knowledge field is both an art and a science"

(Bredillet, $2004 \mathrm{a \& b)"}$

According to PMI (1994), project management involves applying knowledge, skills, tools, and techniques to project activities in order to meet or exceed stakeholder needs and expectations. It is the art of directing and coordinating human and material resources throughout the life of a project to achieve project objectives within specified constraints.

Lock (2003) explains that a large industrial project involves numerous differentiated activities that must focus on one final target. From the commencement of the works to the completion and delivery of the plant, the organizational structure must run smoothly on the basis of cooperation and interaction to meet the obligations undertaken towards the client. With this aim in view, it is essential for a company to possess great capability and experience in planning and optimizing the various project activities, as well as highly advanced management tools and methodologies to control time and cost constraints and to meet the challenging requirements of growing efficiency.

Project management is a specialized branch of management which has evolved in order to co-ordinate and control some of the complex activities of modern industry. The changing business environment of the twenty first century increases the range of activities coming under the periphery of project management techniques and the way projects are managed. Projects are open systems because they exist in an open environment and have to respond to the ever changing dynamics of situations requiring it to become much more adaptive than ever.

According to Seymour et al. (1992) project management is a central strategy in the changes that many organizations are undergoing as they adapt from a stable, machine like model to a more dynamic one in face of environmental turbulence and change. Project managers face difficult task of both fostering flexibility, adaptability and the acceptance of change as a permanent state, and providing support for team members to enable them to live with a process they may experience as stressful and disorientating.

Kerzner (2003) defines project management as the planning, organizing, directing, and controlling of company resources for a relatively short term objective that has been established to complete specific goals and objectives. Project Management is the application of knowledge, skills, tools and techniques to project activities to meet project requirements. Project management is accomplished through the use of the processes such as: initiating, planning, executing, controlling, and closing. The term project management is sometimes used to describe an organizational approach to the management of ongoing operations also referred to as management by projects. In the same many aspects of ongoing operations are treated as projects so as to apply the project management practices easily to them.

\section{Projects vs. operations: the nature of projects}

Every organization acts according to two fundamentals modes: 1 . an operational mode, aiming at the exploitation of competitive advantage and current position on the market and providing profits and renewal or increase of resources and 2. an entrepreneurial mode, or project mode, focusing on the research of new position and new competitive advantage, consuming money and resources. To ensure their sustainability and development, all organizations need to combine both modes. (Declerk in Ansoff, Declerk, \& Hayes, 1976).

It is now appropriate to look at the way an organization is linked to its environment. We can define strategy as a function of linkage between an organization and its environment (Ansoff, 1975). If we consider the operational 
mode, the problem is to optimize performance of the function that is the strategy of penetration of the organization regarding its environment and to optimize the internal performance. On the other hand, in the entrepreneurial mode, the problem is to look at opportunities of expansion and/or diversification and/or reconfiguration, choosing, among a set of possible strategies, the most effective function, and select, among a set of possible organizational structures, the most efficient.

\section{Plans and Projects}

As stated by Gittinger (1982), projects provide an important means by which investment and other development expenditures foreseen in plans can be clarified and realized. Sound development plans require good projects, just as good projects require sound planning. The two are interdependent.

Sound planning rests on the availability of a wide range of information about existing and potential investments and their likely effects on growth and other national objectives. It is project analysis that provides this information, and those projects selected for implementation then become the vehicle for using resources to create new income. Realistic planning involves knowing the amount that can be spent on project activities for a particular kind of investment.

Well-analyzed projects often become the vehicle for obtaining outside assistance when both the company and the external financing agency agree on a specific project activity and know the amount of resources involved, the timing of loan disbursements, and the benefits likely to be realized. But project analysis should not be confined to only those investments for which external financing will be sought. In the words of Gittinger (1982), if carefully designed and high-yielding projects are offset by essentially unplanned investments, then he net contribution to the organizational objectives is substantially undermined.

Projects are a part of an overall development strategy and a broader planning process. Within the broad strategy, analysts must identify potential projects that address the policy and organizational priorities. Generally there are more than one project alternatives available with a company for investment, of these; all the projects being prepared and analyzed should use a consistent set of assumptions about such things as the relative scarcity of investment funds, foreign exchange, and labor. All the project analyses should use the same assumptions about the company policies and objectives to be reflected.

\section{Project Life Cycle}

As maintained by PRINCE2 (2002): "A sequence of phases through which a project must pass. There are a variety of definitions that generally reflect different industry practices... The generally accepted sequence is: pre-feasibility validation of concepts); feasibility (detailed investigation of viability) design; contract (procurement); implementation; commissioning; handover and operation.

Project life cycle generally defines:

(1) The tasks to be accomplished in each phase or sub- phase

(2) The team responsible of each of the phases defined

As advocated Archibald \& Voropaev (2003), there is a general agreement that the four broad, generic project phases are (common alternative terms are shown in parentheses):

(1) Concept (initiation, identification, selection.)

(2) Definition (feasibility, development, demonstration, design prototype, quantification.)

(3) Execution (implementation, realization, production and deployment, design/construct/ commission, installation and test.)

(4) Closeout (termination, including post-completion evaluation.)

The number of phases in a project life cycle depends on a variety of factors like nature of industry, type of output, size of project etc. Kerzner (2003) has developed a theoretical sequence of phases that may be identified with most of the projects as is outlined below:
(1) Conceptual
(2) Planning
(3) Testing
(4) Implementation or Execution
(5) Closure 
It is generally better in planning projects to analyze successive increments or distinct phases of activity; in this way the return to each relatively small increment can be judged separately. Like products follow a product life cycle, projects follow a project life cycle that has certain phases of development.

Dividing a big project in manageable chunks makes the complex task of managing projects easier, these chunks in a sequential form can be termed as project phases which can further be divided into sub-phases and a collection of these phases makes what is called as a project life cycle. Each project phase is marked by completion of one or more deliverables. Although many project life cycles have similar phase names with somewhat similar deliverables required, few are identical. Most have four or five phases, but some have nine or more. Sub-projects within projects may also have distinct project life cycles. Importantly, these phases are not always consecutive in nature but are more simultaneous. Though researchers have suggested certain representative project life cycles, for example, the waterfall model and Muench et. al's (1994) spiral model for the software development life-cycle, Morris's (1994) construction project life cycle and Murphy's (1989) representative life cycle for a pharmaceutical project.

As per Kulkarni et al. (2004), the projects, especially the ones having a longer lifecycle, could be categorised into many phases depending on the functions. For convenience and simplicity points of view, the three commonly known phases is utilised, namely:

(1) Procurement phase: From inception to the financial closure and beginning of works (tendering; dealing with governments, lenders, insurers, pressure groups, experts)

(2) Execution phase: Project execution (site installation till routine processes are reached, significant completion)

(3) Operation and handover phase: From significant completion till the end of defect liability period and handover

As said by Flaatten, McCubbrey, O'Riordan and Burgess (1992), 'project execution' (also known as 'project implementation' phase) is the phase where project manager is responsible for allocating work to the various team members, making sure that the team resources are used where most needed, and ensuring that the workload is balanced. As intermediate deliverables are completed, they are reviewed for verification (that they are correct and abide by project standards) and validation (that they conform to previous work).

Wideman (1987) describes; each of these phases are unique in terms of:

(1) People allotted to them

(2) The budget available for carrying out these phases

(3) Specific time available to finish each of the phases.

\section{Characteristics of a project life cycle}

Risk and uncertainty is highest at the beginning stages of a project and reduces thereafter as the project continues.

The ability of the stakeholders to influence the final characteristics of the project's product and the final cost of the project is highest at the start and gets progressively lower as the project continues. Also the cost of correcting an error increases as the project goes along.

\section{Project Management Tools}

What these tools are used for?

Good project management deals with three factors: time, cost and performance. Projects are successful if they are completed on time, within budget, and to performance requirements. In order to bring the many components of a large project into control there is a large toolkit of techniques, methodologies, and tools. These techniques provide the tools for managing different components involved in a project: planning and scheduling, developing a product, managing financial and capital resources, and monitoring progress. However the success of a project will always rest on the abilities of a project manager and the team members.

\section{Work Breakdown Structure (WBS)}

This tool is related to planning and scheduling a project. Basically it is a functional decomposition of the tasks of the project. The total work of the project is broken down into the major subtasks. It starts with the end objective required and successively subdividing it into manageable components in terms of size and complexity: program, project, system, subsystem, components, tasks, subtasks, and work elements.

Gantt charts

Developed by Harry Gantt in 1916, these charts give a timeline for each activity. They are used for planning, scheduling and then recording progress against these schedules.

PERT/CPM (Critical Path Method) 
Both methods show precedence relationships explicitly. Although the two methods were developed independently during the fifties, they are surprisingly similar. Both methods, PERT and CPM, use a graphic representation of a project that it is called "Project Network" or "CPM diagram", and it is used to portray graphically the interrelationships of the elements of a project and to show the order in which the activities must be performed.

\section{Conclusion}

Therefore we can summarize that projects are unique in nature and much depends on the industry, size, location, nature, complexity, business environment etc. in which they operate. The truth appears to be that the concept of 'one size does not fit all' is a good point to start with in certain cases.

\section{References}

Ansoff, H. (1975). Managing strategic surprise by response to weak signals. California Management Review. 18(2): 21-33.

Ansoff, H., Declerk, R., \& Hayes, R., eds. (1976). From Strategic Planning to Strategic Management. New York: John Wiley and Sons.

Archibald R.D., \& Voropaev, V.I. (2003). Commonalities and Differences in Project Management Around the World: A Survey of Project Categories and Life Cycles, ESC Lille International PM Workshops / IW 3 - OL \& $\mathrm{KM}$.

Bredillet, C. (2004a). Project management governance: A situational approach. EURAM conference. Munich, Germany.

Bredillet C. (2004b). Understanding the very nature of Project Management: a praxeological approach. PMI Research Conference, London.

Declerck, R., Debourse, J., \& Declerck, J. (1997). Le management stratégique: contrôle de l'irréversibilité. Lille: Les éditions ESC Lille.

Declerck, R., Debourse, J. \& Navarre, C. (1983). La Méthode de Direction générale : le management stratégique. Paris: Hommes et Techniques.

Diallo, A., \& Thuillier, D. (2003). The success dimensions of international development projects: the perceptions of African project coordinators. International Journal of Project Management, Pergamon.

Flaatten, P.O., McCubbrey, D.J., O'Riordan, P.D. and Burgess, K. (1992). Foundations of Business Systems (second edition). Andersen consulting Arthur Andersen \& Co., S.C., The Dryden Press.

Gareis, R., Huemann, M. (2000). PM-Competences in the Project-oriented Organization in: The Gower Handbook of Project Management, JR Turner, SJ Simister (ed.), Gower, Aldershot,. p. 709-721.

Gittinger, J.P. (1982). Economic Analysis of Agricultural Projects, Second Edition, A World bank Publication, The John Hopkins University Press, Baltimore and London.

Gittinger, J.P. (1972). Economic Analysis of Agricultural Projects, A World bank Publication, The John Hopkins University Press, Baltimore and London.

Kerzner, H. (2003). Project management, A systems approach to planning, scheduling and controlling. New York: John Wiley and Sons.

Kulkarni, R., Bargstädt, H.J., \& Huckfeldt, J. (2004). Differential role of alliance leadership at various phases on projects in cross-cultural milieu. Proceedings of the IPMA world congress on Project Management. Budapest: Hungary.

Lock, D. (2003). Project Management, Gower Publishing, Eighth edition.

Morris P. W. G. (1994). The management of projects. London: Thomas Telford.

Muench, D., et al. (1994). The management of projects. London: Thomas Telford.

Murphy, P.L. (1989). Pharmaceutical project management: Is it different? Project Management Journal. Newton Square, PA: Project Managempent Institute.

Nilsson, A. \& Söderholm, S. (2005) From blueprints to maps in project management. EURAM, Munich.

Pinto, J. K., \& Slevin, D. P. (1988). Project Success: Definitions and Measurement Techniques. Project Management Journal, 19(1), 67-72.

PMI (2000). A Guide to the Project Management Body of Knowledge. Newtown Square, PA: Project Management Institute. 
PMI (1994). A guide to the Project Management Body of Knowledge. Newtown Square, PA: Project Management Institute.

PRINCE2, (2002). Managing Successful Projects with PRINCE2. Her Majesty's Treasury, The Stationery Office. Norwich.

Seymour, D.E., Hoare, D.J., \& Itau, L. (1992). Project Management Leadership Styles: Problems of resolving the continuity-change dilemma, 11th INTERNET World Congress on Project Management, Florence: Italy.

Tuman, G.J. (1983). Development and implementation of effective project management information and control systems, in Cleland, D.I. \& King, W.R. (eds.) Project management handbook. New York: Van Nostrand Reinhold Co., 495-532.

Turner, J.R. (1999) The handbook of project-based management: improving the processes for achieving strategic objectives. 2nd ed. London : McGraw-Hill

Wideman, R.M. (1987). Project Management Body of Knowledge, Project Management Institute, Upper Darby, PA, Glossary of Terms, 22. 